\title{
Az SRTM-1 felszínmodell korrigálása Magyarországra
}

\section{Józsa Edina1 - Fábián Szabolcs Ákos²}

\author{
${ }^{1}$ doktorandusz, Pécsi Tudományegyetem, Földtudományok Doktori Iskola, E-mail: edina.j0zs4@gmail.com \\ ${ }^{2}$ adjunktus, Pécsi Tudományegyetem, Természet-és Környezetföldrajzi Tanszék, E-mail: smafu@gamma.ttk.pte.hu
}

\begin{abstract}
Absztrakt
A közel globális lefedettséget nyújtó, szabadon hozzáférhetö digitális felszínmodellek (pl. SRTM-1, SRTM-3, ASTER GDEM) széles körben elterjedt eszközei a modern földtudományi vizsgálatoknak. A kutatás során a 30 méter felbontású SRTM-1 modell korrigálását végeztük el Magyarország területére, szabadon hozzáférhetö felszínborítási adatok és nyilt forráskódú térinformatikai eszközök alkalmazásával. A folyamat során a vízfelszinek, az erdök és a beépitett területek hibás magassági adatait kezeltük, csökkentettük a modellt terhelö zaj, illetve a kiugró hibák mértékét. A valós magassági értékek közelitésével a felszínmodell geomorfológiai elemzések kivitelezésére alkalmas alapállománynak tekinthetö, valamint térképészeti munkákban is jobban megfelel a domborzat vizualizációjára.
\end{abstract}

Kulcsszavak SRTM-1, globális digitális magasságmodell, geomorfometria, Magyarország

\section{DOI: 10.17799/2016.1.13}

\section{Bevezetés}

\subsection{Az SRTM projekt}

A Föld felszínének digitális reprezentációja céljából hozta létre a National Aeronautics and Space Administration (NASA), a National Geospatial-Intelligence Agency (NGA) és a Deutsches Zentrum für Luft- und Raumfahrt (DLR) közösen az általunk is alkalmazott digitális magassági modellt. A globális térképezési projekt célja egy olyan magassági állomány előállítása volt, amely egységes minőségü, pontos, nagy részletességü és aktuális információkat szolgáltat a modern földtudományok számára, elősegítve mind a civil, mind a katonai alkalmazások fejlődését. A Shuttle Radar Topography Mission (SRTM) keretében 2000 februárjában az Endeavour ürsikló fedélzetéről duál-antennás interferometrikus radarrendszer (InSAR) segítségével 11 napos felvételezés során állították elő a modell nyers adatait az északi szélesség $60^{\circ}$ és déli szélesség $56^{\circ}$ között, tehát a szárazföldek közel 80\%-áról (Farr et al., 2007).

Ezt követően a NASA Jet Propulsion Laboratory végezte el a magassági adatok kinyerését, a modell verifikálását és részletes hibaelemzését. 2003-tól vált elérhetővé az 1. verzió, amit a továbbiakban különböző kutatócsoportok utófeldolgozása révén három újabb verzió követett. $\mathrm{Az}$ USA területére 1 szögmásodperces, a világ többi részére 3 szögmásodperces felbontással volt hozzáférhető az adat (USGS SRTM 1 Arc-Second Global termékleírás).
Az SRTM modell az adatnyerési eljárás miatt nem a valós terepi magasságokat reprezentálja, a fák lombkoronájáról (annak ellenére, hogy a felvételezés az északi félteke telén zajlott) és az építményekről visszaverődő jelek révén egyes térségeket magassági hiba terhel. Néhány cella esetében akár 100 métert is elérő pozitív vagy negatív irányú kiugró hibák is előfordulnak. További súlyos problémát jelentett az elkészült modell horizontális elcsúszása is, amelyet a lehetőségekhez mérten szintén korrigáltak idővel. A felszínmodell a hibaértékek tekintetében teljesíti a kartográfiai elvárásokat, az 1 szögmásodperces modell celláinak 90\%-a esetében az abszolút magassági hiba 16 méter alatt marad, horizontálisan a geolokációs hiba pedig kisebb 20 méternél, tehát szubpixeles. Európa területén ennél még kedvezőbbek is a hibastatisztikák, az abszolút vízszintes hiba 8,8 méter, az abszolút magassági hiba 6,2 méter, a relatív magassági hiba pedig 8,7 méter (Rodriguez et al., 2005).

A modellnek az elmúlt 15 évből számtalan geomorfológiai, hidrológiai, talajtani alkalmazása ismeretes. Az SRTM adatok felhasználása pedig újabb lendületet vett, amikor 2014 szeptemberében az Egyesült Állomok vezetése bejelentette, hogy a világ többi területére is szabadon hozzáférhetővé teszik az 1 szögmásodperces állományt (NASA JPL hírek). Korábbi kutatásaink során már foglalkoztunk globális magasságmodellek korrigálásával és geomorfológiai alkalmazhatóságukkal (Józsa, Fábián \& Kovács, 2014, Józsa, 2015), 2016-ban pedig 
újabb módszertani megfontolásokkal belekezdtünk, egy Magyarország területét lefedő, javított SRTM-1 állomány létrehozásába.

\subsection{A korrigált modell jellemzői}

A korrigálás célja egy információ-tartalmában és vizuálisan javított SRTM-1 felszínmodell előállítása volt, amely jobban megfelel geomorfológiai kutatások kivitelezésére is. Az általunk előállított adat szabadon hozzáférhető és használható kutatási célokra, annak megfelelő hivatkozásával. A Korr.DFM a szerzőktől, illetve a PTE Földrajzi Intézetének hálózatáról érhető el.

A korrigált modell hazánk területét, illetve az országhatár mentén további $5 \mathrm{~km}$-es sávot fed le, összesen 113083019 darab 30×30 méter felbontású négyzetes raszter cellával. A modellt Egységes Országos Vetületi rendszerbe (EOV) transzformáltuk és GeoTIFF formátumban tettük elérhetővé. A befoglaló négyzet határainak EOV koordinátái: 367920 (É), 38820 (D), 421410 (Ny), $942390(\mathrm{~K})$. A teljes terület egy fájlban tölthető le, nem készítettünk kisebb szelvényeket, vagy tematikus kivágatokat.

A korrigált modell esetében nincs adathiány, a legalacsonyabb cellaérték 23,36 méter, a legmagasabb érték pedig 1043,62 méter. A vetületi transzformációk során alkalmazott bilineáris átszámítási módszer miatt az értékek kis mértékben eltérnek az eredeti földrajzi koordináta-rendszerben elérhető SRTM-1 modell magasságaitól. Amennyiben más domborzatmodellekkel kerül a korrigált modell együttes alkalmazásra, úgy javasolt a horizontális elcsúszás ellenőrzése, szükséges esetben korrigálása.

Az eredeti modell és a korrigált SRTM-1 felszínmodell különbségei az 1. ábrán tekinthetőek át.

\subsection{Alapfogalmak}

Sem az angol, sem a magyar szakirodalomban nem alakult ki egységes szóhasználat a magassági modellek terén (Telbisz, Székely \& Timár, 2013). A hazai szakirodalom
(Mélykúti, 2007) elsősorban három magassági adatrendszert különböztet meg:

- Digitális Domborzat Modell (DDM) - az abszolút magassági adatok a terep fizikai felszínéről szolgáltatnak információt,

- Digitális Felszín/Felület Modell (DFM) - a földfelszín és a rajta található objektumok magassági értékeiröl is tájékoztat,

- Digitális Szintvonal Modell (DSZM) - a domborzatot szintvonalak segítségével írja le.

További problémát okoz, hogy egyes kutatók szerint az ún. globális domborzatmodellek (SRTM, ASTER GDEM) nem sorolhatók egyik kategóriába sem, mivel a horizontális felbontás meghaladja a felszíni objektumok méretét, így azok magasságmódosító hatása az egész cella területén érvényesül (Farr et al., 2007).

Mindezeket figyelembe véve a legpontosabb, ha az SRTM-1 modellt felszínmodellként (DFM) értelmezzük, míg az általunk előállított modellre korrigált felszínmodellként hivatkozunk (Korr.DFM). A domborzatmodell megnevezést nem tekintjük helyénvalónak, mivel az értékek továbbra sem a valós magassági adatokat reprezentálják, illetve visszamaradtak különféle hibával terhelt cellák.

\section{Módszerek}

\subsection{A felhasznált adatok ismertetése}

Az alkalmazott „SRTM 1 Arc-Second Global” termék az amerikai U.S. Geological Survey (USGS), NGA és NASA közös terméke. A Magyarország és környezetének területét lefedő SRTM-1 $1 \times 1^{\circ}$ felbontású 28 raszter fájlt az USGS Earth Resources Observation and Science (EROS) Center honlapjáról töltöttük le, GeoTIFF formátumban. Felbontása 1 szögmásodperc, amelyet leggyakrabban 30 méteres négyzetes cellákra konvertálva alkalmaznak. Az eredeti állományon elvégzett korrekciók közé tartozik a kiterjedt vízfelszínek elsimítása, illetve a kiugró hibák és adathiányok korrigálása (USGS SRTM

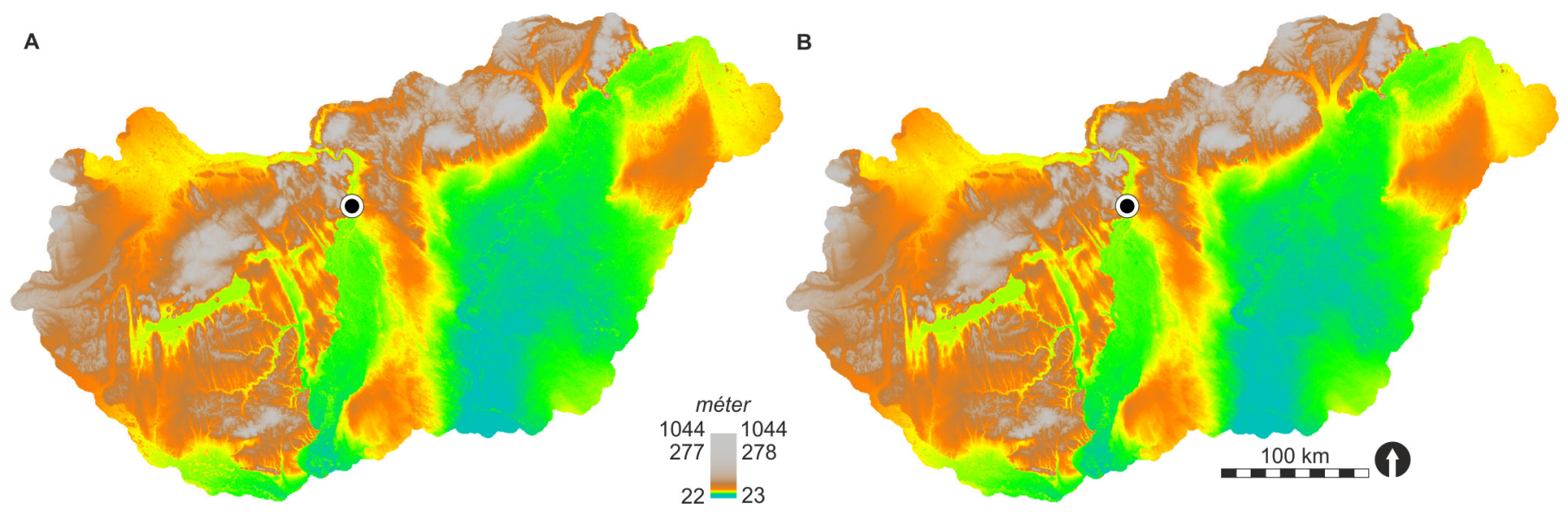

1. ábra: Az SRTM-1 felszínmodell korrigálás elótti (A) és javított (B) verziójának színfokozatos ábrázolása hisztogram kiegyenlítéssel. 
1 Arc-Second Global termékleírás). A modellhez alkalmazott alapfelület a WGS84 ellipszoid, a felszínmodell magassági értékei az ellipszoidi magasság és az EGM96 geoidmodell különbségeként kerültek meghatározásra (Farr et al., 2007).

A vízfelszínek további korrigálásához a NASA és NGA által létrehozott vízmaszkot alkalmaztuk (SRTM Water Body Database V2.1 2003), amely vektor fájlként, ESRI shapefile formátumban értünk el. Ezt egészítettük ki az OpenStreetMap (OSM) adatbázisából nyert adatokkal, amihez a területhasználati poligonok közül a víztározók és tavak kerültek a megfelelö címkék alapján leválogatásra. Az OSM adatbázis poligonjait vettük alapul a beépített területek lehatárolása esetében is.

$\mathrm{Az}$ erdőterületek lehatárolására a Google Earth Engine csapata és a University of Maryland kutatói által 2013-ban közreadott erdőborítás állományt alkalmaztuk. A kutatócsoport Landsat műholdképek felhasználásával a 2000-es évektől kezdődően több időszakra elkészítették a fás területek raszteres térképét (Hansen et al., 2013), így a megfelelő időpontra vonatkozó adat állt rendelkezésünkre. Emellett a raszteres állomány cellamérete 25 méter, ami az SRTM modell korrigálására már jól alkalmazható.

A korrekció elvégzésének első lépésében az egyes állományokat UTM (zone 34) vetületü GRASS GIS mapsetbe importáltuk, valamint egységesen 30 méteres cellaméretű raszterekké konvertáltuk.

\subsection{Az alkalmazott szoftverek áttekintése}

A korrigálási algoritmus összeállítása, illetve a modell minőségének ellenőrzése során a felszínmodell és a további térképek kezelését, elemzését modern térinformatikai eszközök és módszerek alkalmazásával valósítottuk meg. A szoftverek kiválasztásakor meghatározó szempont volt, hogy az elérhető bővítmények révén az eljárás kivitelezéséhez szükséges eszköztár rendelkezésünkre álljon. A választott GRASS GIS 7.0.5 és Quantum GIS 2.14.8 térinformatikai alkalmazások, valamint a statisztikai vizsgálatok lebonyolítására használt $\mathrm{R}$ 3.0.2 program GNU GPL (General Public Licence) oltalom alatt álló szabad és egyben nyílt forrású szoftverek (FOSS - Free Open Source Software).

\section{Eredmények}

\subsection{A modell korrigálása}

Az SRTM-1 modell korrigálása során öt fó feladatrész elvégzésére volt szükség, ezek mindegyike több lépésből tevődik össze. E feldolgozási feladatok a kivitelezés sorrendjében a következők:

- vízfelszínek egységes környezeti magasságra hozása,

- erdővel borított térszínek magassági adatainak pontosítása,
- beépített területek értékeinek közelítése a valós magasságokhoz,

- zajszerü hibák mértékének csökkentése,

- kiugró hibák eltávolítása.

A felsorolt hibákkal terhelt cellák pontosítása nem csak információtartalmát tekintve, de vizuálisan is jelentős mértékben javította a felszínmodellt. A korrigálás során szem elött tartottuk, hogy könnyen kivitelezhető megoldásokat alkalmazzunk, és általánosságban többet javítsunk a magassági értékeken, mint amennyit egy-egy speciális esetben ronthattunk. Az egyes lépések hatását folyamatosan nyomon követtük a felszínmodell négyszeres túlmagasítással készített domborzatárnyékolásos megjelenítésével.

\subsubsection{Vizfelszinek magasságainak kezelése}

Az SRTM modell jelenlegi változatának elkészítésekor csak a 600 méternél hosszabb tavakat, valamint a 183 méter szélességet meghaladó vízfolyásokat korrigálták. Utóbbiak esetében a torkolat felé fokozatosan csökkenő „vízfelszínt” illesztve a modellbe (Slater et al., 2006). Ennek megfelelően jelentős folyóink magasságai már javítva vannak, a kisebb vízfolyásaink esetében pedig szükségtelen lett volna ezt a bonyolultabb eljárást alkalmazni, mert nem vehetőek ki a völgyekben az eltérő magasságok.

A tófelszínek javítását azért ítéltük szükségesnek, mert a kisebb tavak esetében is jelentős hibák terhelik a cellákat, amelyek egyszerű vizuális elemzési módszerrel is szembetünőek (2. ábra). Az általunk kiegészített vízmaszk használatával és Slater et al. (2006) módszerét alkalmazva a tavakat egy a partokhoz igazodó magasságra

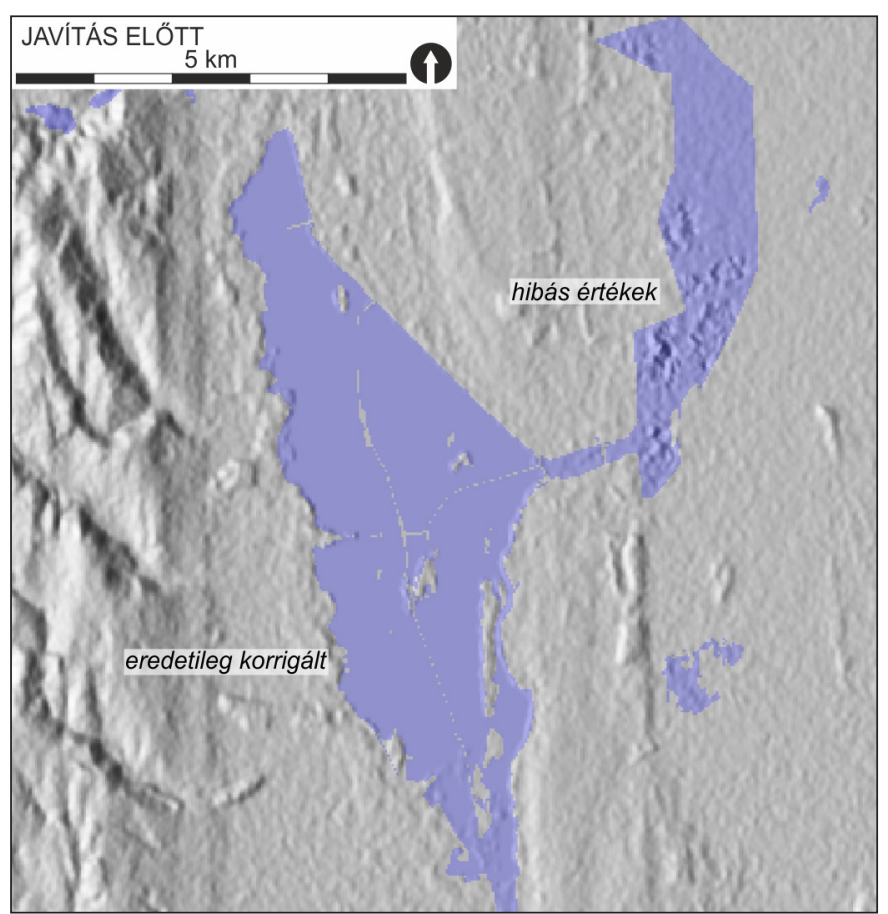

2. ábra: A Kis-Balaton eredetileg korrigált és az ÉK-i részek hibás magasságai a bóvített vízfelszín térképpel. 
töltöttük fel, külön-külön figyelembe véve a vízfelszínre és a partvonalra eső cellák értékeinek alakulását. Ebben az eljárásban érintett cellák a felszínmodell 0,6\%-át teszik ki.

\subsubsection{Erdöfelületek magassági értékeinek pontositása}

A nemzetközi (Gallant, Read \& Dowling, 2012, Köthe \& Bock, 2009) és a hazai (Seres \& Dobos, 2009, Ungvári, 2015) szakirodalomban is többféle példa olvasható az erdőterületek magassági értékeinek korrigálásáról az SRTM modellek esetében. Ennek előfeltétele, hogy megfelelő felbontású állománnyal rendelkezzünk az erdőborításról, lehetőleg a felszínmodell készítésének időszakából. Az általunk alkalmazott 25 méter felbontású, az erdőterületek 2000-es kiterjedését reprezentáló térkép (Hansen et al., 2013) megfelel e kritériumoknak. Több terület esetében megvizsgáltuk az erdőborítás térkép illeszkedését a domborzatárnyékolásos térképen kivehetó erdőszegélyekkel, ami alapján szintén alkalmasnak ítéltük az állományt a fás térszínek lehatárolására. További előnye, hogy nem egyszerüen arról ad információt van-e adott cellán fa, facsoport, hanem százalékos értékben megadja az 5 méternél magasabb vegetációval borított terület cellán belüli arányát. Az 3. ábra jól mutatja, hogy hazánk területének jelentős részén kell foglalkoznunk az erdők jelenlétéből adódó magasságtorzítással az SRTM-1 modell esetében.

A probléma kezelése során figyelembe kellett vennünk a domborzati viszonyokat, mivel adott lejtőszög felett a rendelkezésre álló módszerek nem képesek pontos információt szolgáltatni az erdős és erdő nélküli cellák magasságkülönbségeiről. Az alacsony reliefü térségek elkülönítéséhez nem alkalmazhattuk egyszerüen a százalékos lejtőértékeket, hiszen az erdőterületek határán is meredek peremeket találtunk. Ennek megfelelően egy $11 \times 11$ kör alakú szomszédságon átlagolt felszínről készített százalékos lejtőérték térkép 7,5\% alatti értékei alapján határoltuk le a területet. Emellett az algoritmusnak képesnek kell lennie a kis kiterjedésű facsoportok és az igazi kihívást jelentő Gemenci-erdöhöz hasonló méretü összefüggő erdőfoltok területének kezelésére is. A korábbi tanulmányokban (Seres \& Dobos, 2009, Ungvári, 2015) az erdők javításához a foltok szegélyénél számított különbségekböl állapítottak meg egy átlagos értéket vagy a szegélyekből kiindulva interpoláltak egy erdő-magasság felszínt (Gallant et al., 2012), amelyet kivontak

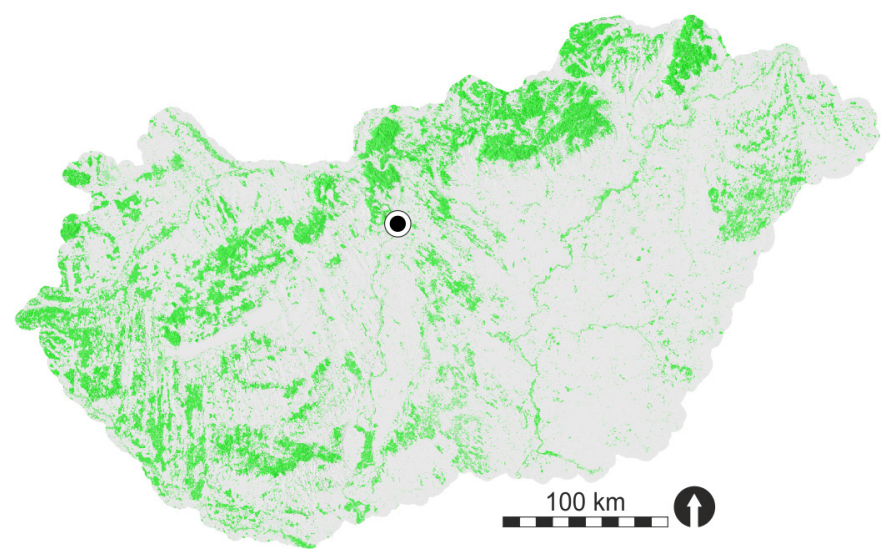

3. ábra: Magyarország fás vegetációval borított térszínei 2000-ben.

az eredeti modellből. Az általunk alkalmazott algoritmus során igyekeztünk a domborzat hatását, illetve az erdőterületen belül a famagasságok változásait is a lehető legpontosabban figyelembe venni, így egy több lépésből álló módszert állítottunk össze (4. ábra). Első lépésben mi is a szegélyek körüli értékekből becsültük meg adott celláknál az erdőfolt magasságát. Ebből kiszürtük a valótlan értékeket, figyelembe véve a faborítási arányt és a domborzati viszonyokat. Ezt követően IDW eljárással a teljes erdőfoltra interpoláltuk a magasságokat, amelyeket végül a Topographic Position Index (TPI) értékek alapján módosítottunk, hogy az erdőborítás térképen nem szereplő irtások területét ne módosítsuk túlzottan negatív irányba. Az alkalmazott korrekció összességében a cellák 21,7\%-ának magassági értékében okozott változást.

\subsubsection{Beépített területek korrigálása}

A beépített területek korrigálása során módszertani akadályt jelent az a korábban már említett sajátosság, hogy a felszíni objektumok egységesen, elmosódva módosítják a cellák magasságát, amit igen nehéz kiszürni. A Budapest

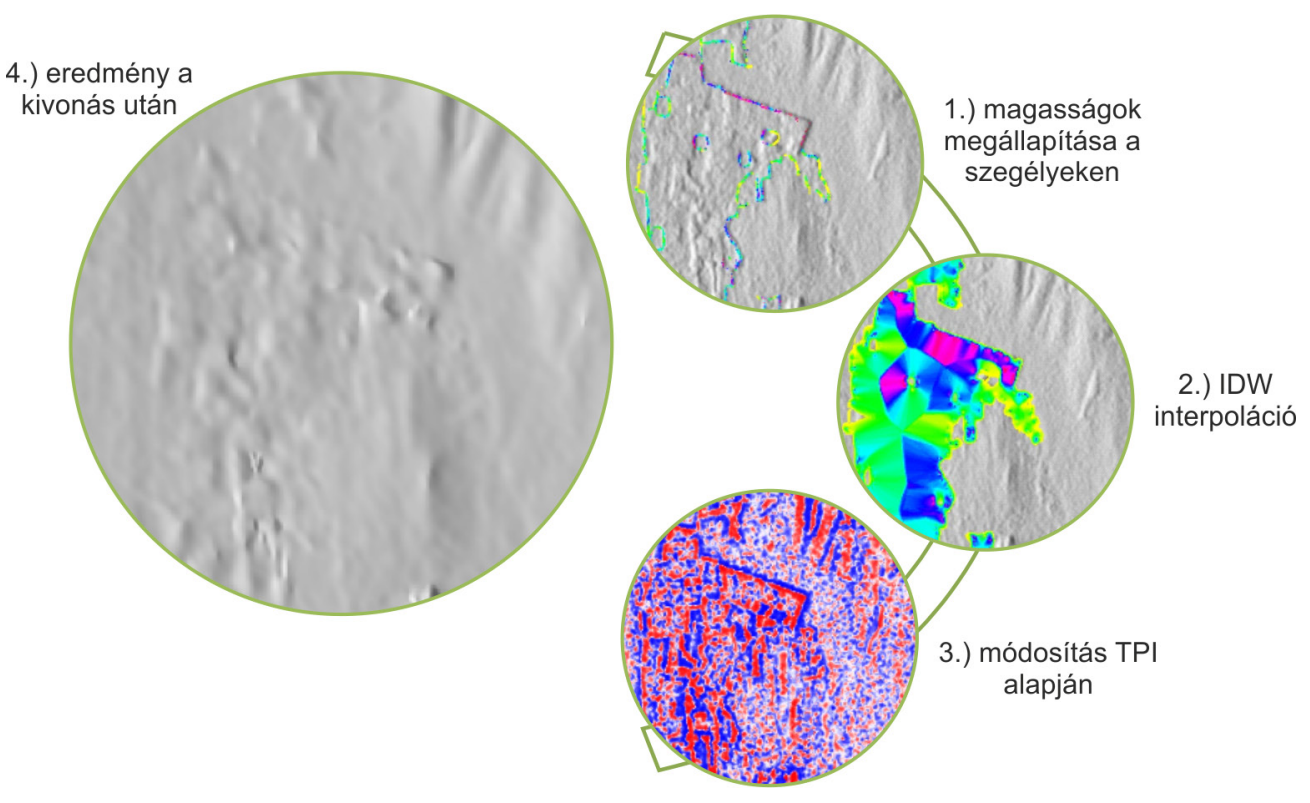

4. ábra: Az erdőterületek korrigálásának lépései. 


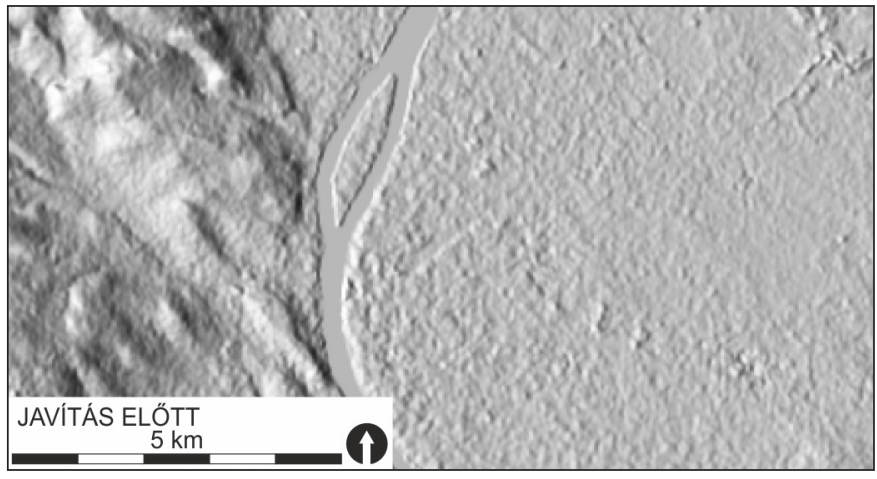

5. ábra: Budapest részlete a korrigálás elótti SRTM-1 modellból készített domborzatárnyékolásos térképen.

környéki kivágat esetében egyértelmúen látszik, hogy az értékek nem a valós felszínt adják vissza. A modell az épületek jellegétől, méretétől, a beépítettség sürüségétől függően módosított magasságokat reprezentál (5. ábra).

A falvak, városok elhelyezkedését, illetve egyes esetekben az építmények helyzetét a már említett OSM adatok alapján határoztuk meg, majd szomszédsági vizsgálatokat alkalmazva válogattuk le azokat az épületeket tartalmazó cellákat, cellacsoportokat, melyek jelentősen kiemelkednek környezetükböl. Ebben az esetben is szükség volt a domborzati viszonyok figyelembe vételére, hogy a meghatározott magasságokat ne torzítsa nagymértékben a felszín változatossága. A kisebb települések esetében reálisabb eredmények voltak elérhetőek, hiszen a cellakörnyezetböl pontosabban lehetett megállapítani a valós felszínhez közelebb eső magasságokat. Ez a korrekciós lépés a modell $0,8 \%$-át érintette.

Fontosnak tartjuk megjegyezni, hogy geomorfológiai kutatások során célszerü lehet a sürün beépített, magas

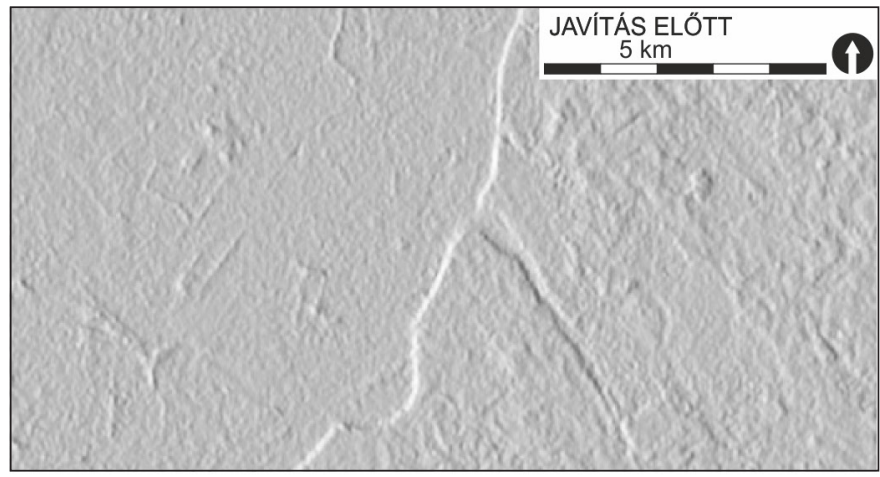

Sárköz - Illancs (Hajós)

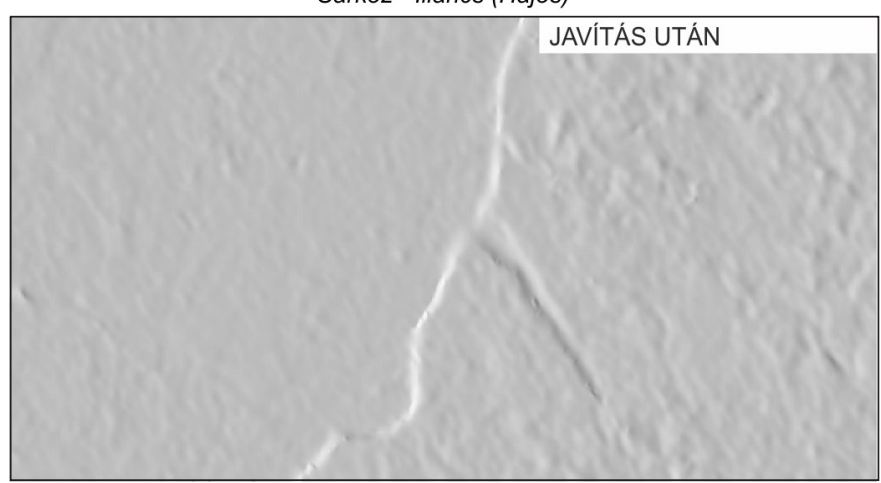

6. ábra: A zajszưrés szemléltetése eltérō reliefú térségekben. épületekkel borított térszínek kimaszkolása, illetve a levezetett térképek értelmezésekor is fokozott figyelemmel kell eljárni.

\subsubsection{Zajszürés}

Az SRTM-1 elóállítási technikája miatt a felszínmodellt zajszerü hiba is terheli. Korábbi kutatások (Gallant et al., 2011) és saját tapasztalataink is azt mutatják, hogy ez a hiba általában 2-3 métert ér el, nincs irányítottsága és egyértelmü területi korrelációt sem mutat. A domborzatárnyékolásos megjelenítés esetén jól kivehető az is, hogy az alacsony reliefü térszíneket jobban érinti. Gallant (2011) kidolgozott egy adaptív simítási eljárást a zaj mérséklésére, azonban a módszer tesztelését követően elvetettük annak alkalmazását. A modellen megjelenő zaj csökkentése érdekében Sun, Rosin, Martin \& Langbein (2007) által kifejlesztett adaptív simítási algoritmust használtuk, amely telepíthető bővítményként GRASS GIS-hez (r.denoise), illetve Windows alatt szabadon hozzáférhető alkalmazásként is elérhető. A simítás mértékét az alkalmazott iterációk számával, míg a formák, élek megtartását egy külön határértékkel szabályozhatjuk. Számos beállítás tesztelése után 7-es iteráció és 0,99 -es élmegtartás mellett döntöttünk, amely egyezik a fejlesztők által az SRTM modell esetében bemutatott értékekkel (Stevenson, Sun \& Mitchell, 2010). A korábbi lépések a hazánk területét lefedő modellnek eddig csak töredékét érintették, azonban ezzel az eljárással gyakorlatilag minden cella értékén módosítottunk kis mértékben.

A kiindulási és a simított modellről készített túlmagasított domborzatárnyékolásos térkép alátámasztja a módszer eredményességét síksági és középhegységi térségek
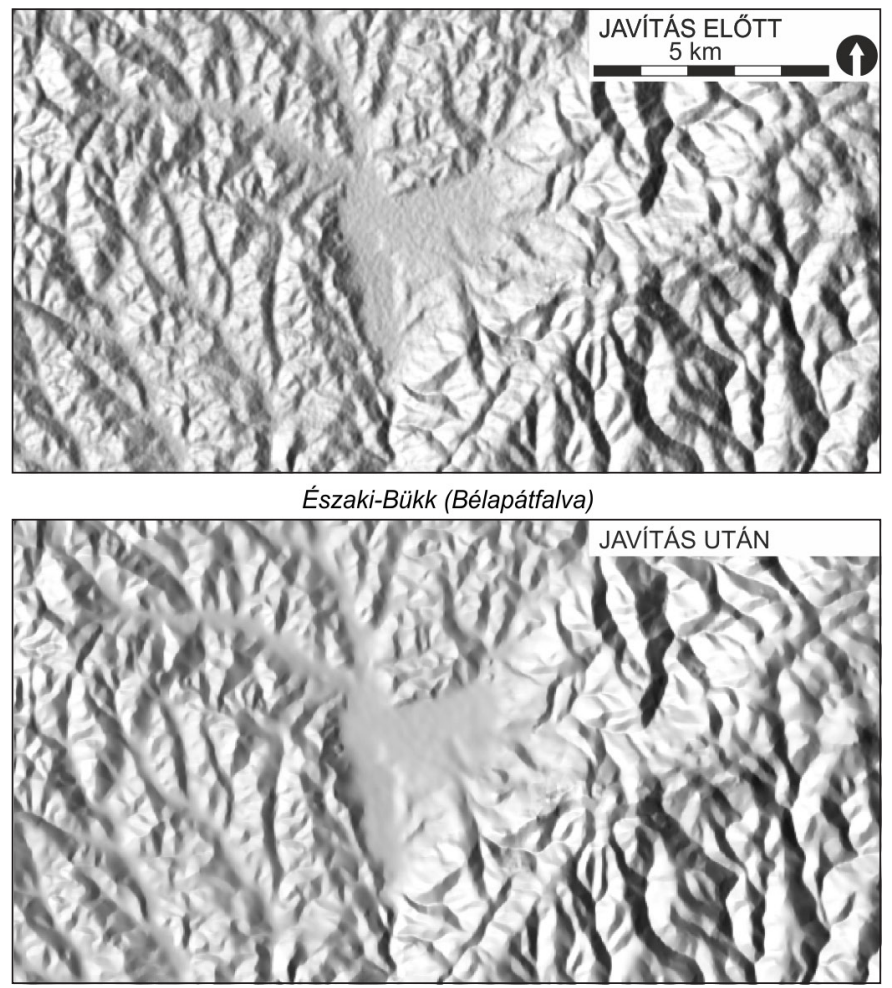
esetében is (6. ábra). A Kalocsai-Sárköz és az Illancs területének találkozásánál, Hajós környékén kiválasztott sík térség esetében jól követhető a Duna által létrehozott perem. A javítások előtti ábrán szembetủnőek a fás területek, valamint egyértelmüen kivehető a modellt terhelö zaj is. A javítás során megőriztük a perem jellegét, mindemellett jelentős simítás érzékelhető. Az Északi-Bükk területéről választott középhegységi mintaterület jó példáját adja az élmegtartás jelentőségének. A simító algoritmus alkalmazása után is kivehetőek a kisebb völgyek, gerincek, míg a központi medencetérség sík felszínén, ahol erösebb simításra volt szükség, szintén hatékony volt a zajszürés.

\subsubsection{Kiugró hibák javitása}

A kiugró hibák jellemzően a topográfiával össze nem egyeztethető alakzatok, pl. lyuk- vagy árokszerü bemélyedések, pontszerü vagy nagyobb kiterjedésü kiemelkedések. A javításhoz felhasznált módszer Neteler (2005) eljárásának egy a domborzati viszonyoknak megfelelően módosított változata. A módszer elve, hogy az eredeti felszínt egy átlagolt felszínhez viszonyítva meghatározhatóak azok a pont vagy kisebb foltszerü területek, ahol a cellakörnyezet szórásából származtatott határértéket meghaladja a két felszín különbsége, tehát kiugró hibáról beszélhetünk. A nagyobb foltszerü hibák esetében ehhez még a kitettségek változékonyságát is hozzávettük a pontosabb lehatárolás érdekében. A hibás értékeket ezzel a módszerrel a környezet átlagértékére tudtuk cserélni, ami nem minden esetben érte el a terület teljes korrigálását. A módosítások mindössze a cellák 0,04\%-át érintették.

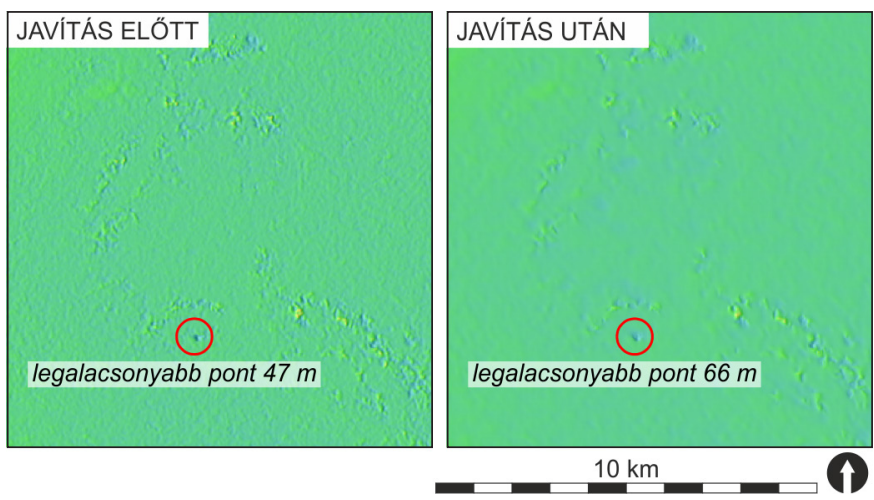

7. ábra: A Kunkápolnási-mocsár magassági értékeinek változása.

Úgy vettük észre, hogy ilyen hibák a mocsaras, lápos területeken jelentkeznek inkább. Bár geomorfometriai szempontból hátrányosak, azonban geomorfológiai megközelítésben elöny lehet, hogy elrendeződésükböl egykori meanderek, vizenyős területek elhelyezkedésére következtethetünk. A kiugró hibák szemléltetésére a Hortobágyon található Kunkápolnási-mocsár magassági értékeinek módosítását mutatjuk be (7. ábra).

\subsection{A korrekció ellenőrzése}

\subsubsection{Pontosságvizsgálat}

Az SRTM-1 modell korrigálása során elért változásokat az eredeti és a köztes modellek magassági értékei közötti eltéréseket jellemző statisztikai mérőszámok elemzésével, a hibaértékekből képzett hisztogramok vizsgálatával, és a különbségtérképek segítségével minden lépés után ellenőriztük.

A legrészletesebben és talán leglátványosabban a raszter-raszter összevetéssel készített, a kiindulási és a Korr.DFM különbségeit tartalmazó térkép mutatja be az eltérések mértékét és elhelyezkedését. A modellek eltéréseinek előjeleihez, valamint a korábban bemutatott hibahatárok szerinti kategóriákhoz igazított színskálával a térkép igazán szemléletessé vált (8. ábra). Jól kivehető, hogy a domborzati viszonyoknak megfelelöen korrigált erdőterületek esetében az eredeti modell legalább 6 méterrel, de egyes térségekben akár 16 méterrel is magasabb volt az újonnan kapott értékeknél. A feltöltött térségek esetében nem szembetünő a sötétkék szín előfordulása, tehát általánosságban véve 6 méternél nagyobb mértékben sehol nem növeltük a cellák magasságát. Feltöltésre elsősorban a szük völgyekkel felszabdalt dombsági és középhegységi térségeink esetén találunk példát, mivel a módszertan sok esetben épült szomszédsági környezet átlagolásából levezetett értékekre. Mindezek mellett szembetűnő még az alföldi térszíneken a világos árnyalatú piros és kék színű cellák váltakozó előfordulása, amit a zajszerü hiba korrigálásának tulajdonítunk.

Mindez számszerüsítve azt jelenti, hogy az előállított Korr.DFM esetében a legnagyobb mértékü feltöltés a 72 métert, míg levágás a 42 métert éri el. Ettől eltekintve azonban az eltérések abszolút értékének átlaga mindöszsze 1,11 méter, az értékek szórása pedig 1,84 méterben állapítható meg. Az SRTM projekt során a teljes adatállományra és az európai térségre megállapított magassági hibaértékek figyelembe vételével az eltéréseket kategóriákba soroltuk (Farr et al., 2007). A magassági eltérések kategóriánkénti megoszlásáról az 1. táblázat szolgál információval.

1. táblázat: A magasságmodellek különbségeinek aránya.

\begin{tabular}{cc}
\hline Kategória & Érintett cellák aránya \\
\hline$>=16 \mathrm{~m}$ & $0,01 \%$ \\
$6-15,99 \mathrm{~m}$ & $2,54 \%$ \\
$1-5,99 \mathrm{~m}$ & $20,87 \%$ \\
$-0,99-0,99 \mathrm{~m}$ & $67,26 \%$ \\
$-1--5,99 \mathrm{~m}$ & $9,32 \%$ \\
$-6--15,99 \mathrm{~m}$ & - \\
$<=-16 \mathrm{~m}$ & - \\
\hline
\end{tabular}

Egy másik hagyományosnak tekinthető eljárás a módosítások ellenőrzésére, hogy négyszeres túlmagasítású domborzatárnyékolásos térképeken, illetve keresztmetszeteken keresztül általunk jól ismert térségek esetében 


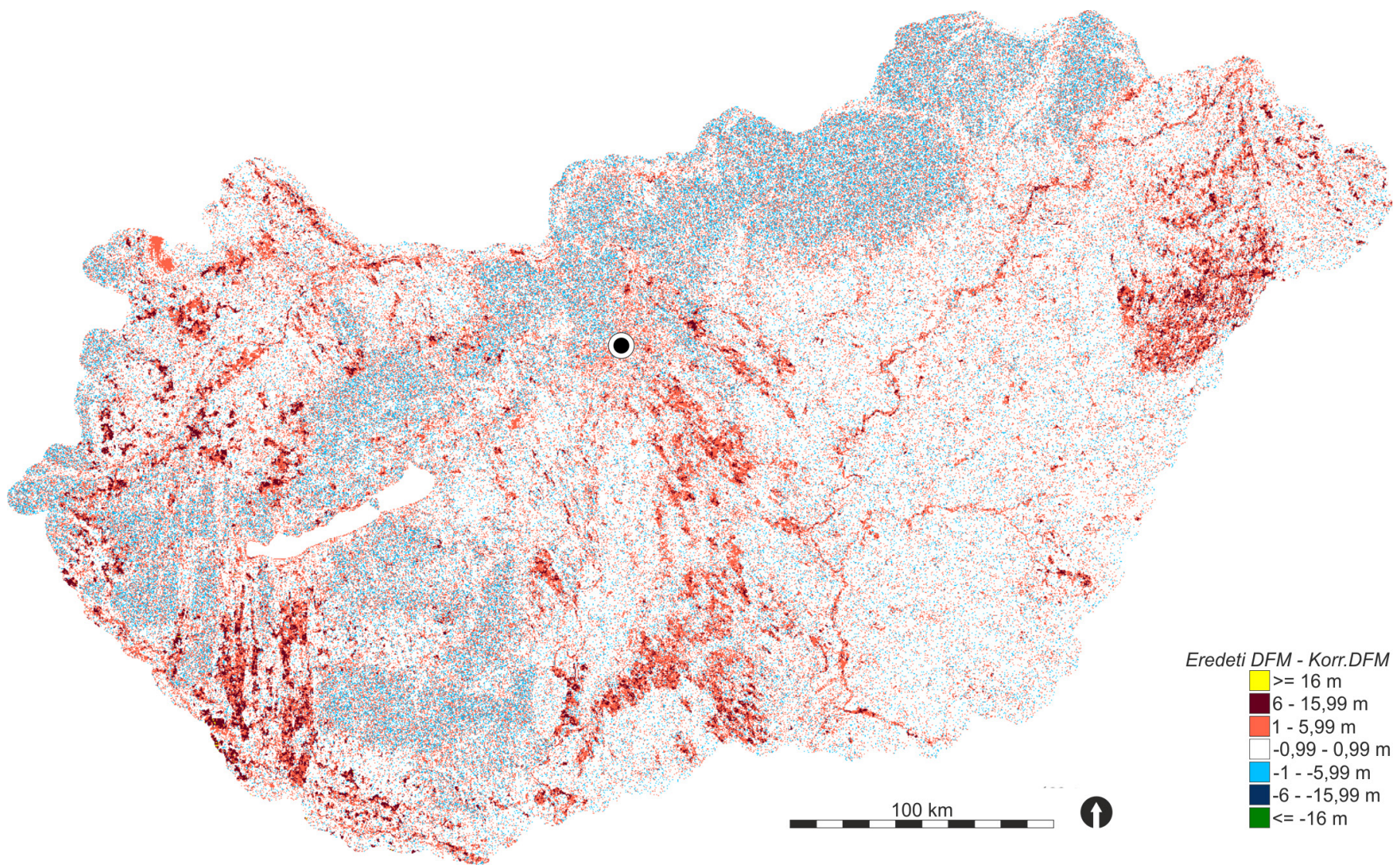

\section{8. ábra: Az eredeti és a korrigált modell magasságértékeinek változását mutató különbségtérkép.}

tárjuk fel a változásokat. Az 5 fö korrigálási folyamat hatásait jól reprezentáló keresztmetszeteket mutat be a 9. ábra.

A Korr.DFM minőségének ellenőrzésére a legmegfelelőbb módszer megbízható referencia domborzatmodellekkel való raszter-raszter összevetés és a hibastatisztikák megállapítása. Korábbi kutatásaink során a Dél-Dunántúlról 5 természeti és társadalmi viszonyait

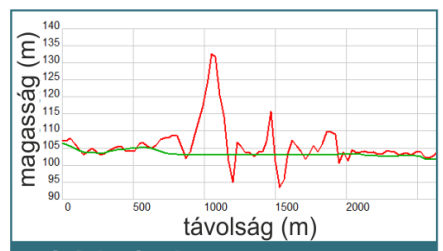

\section{vízfelszinek}

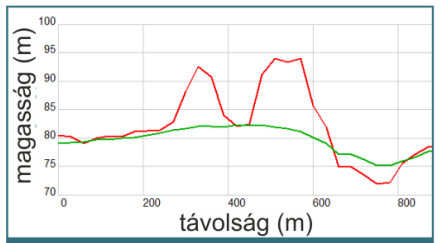

beépitett területek

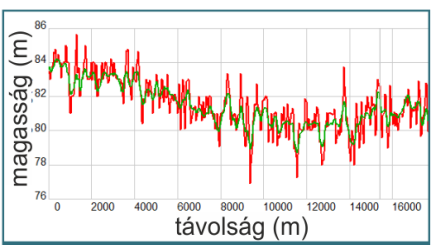

zajszürés
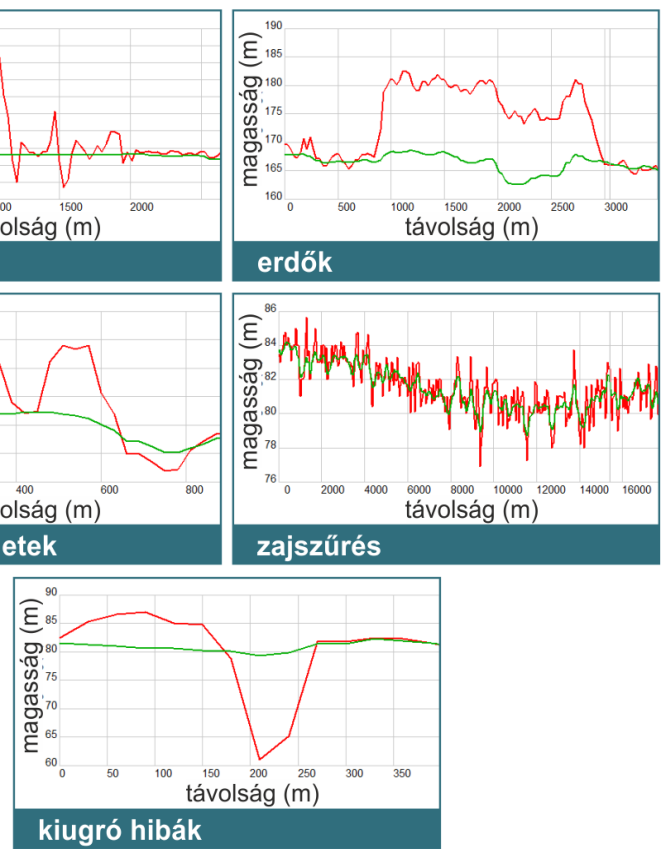

9. ábra: A korrekciók hatásait szemléltető keresztmetszetek (piros - eredeti SRTM-1, zöld - Korr.DFM). tekintve különböző, középhegységi, dombsági és síksági jellegü mintaterületre állítottunk elő szintvonalakból DDM-et. Az SRTM-1 horizontális elcsúszása (Farr et al., 2007), illetve a felbontásbeli és vetületi konverziók miatt fellépö elmozdulások kiküszöbölése érdekében az egyes modellekről leválogatott csúcsokat fedésbe hoztuk, így biztosítva a referencia DDM-ek és az SRTM-1 modellek közti legnagyobb korrelációt (Reuter, Strobl \& Mehl, 2011). Minden esetben a felszínmodellekből a referencia DDM-eket kivonva állítottuk elő a különbségtérképeket.

Az eredeti modell és a referencia DDM-ek különbségértékeinek átlaga 0,20 méter, míg a medián -1,50 méter. Ennek hátterében az áll, hogy az SRTM-1 alábecsüli a valós terepi magasságokat és a fákkal borított térségek hibásan megemelt értékei kompenzálják ezt. A Korr.DFM-ből számított különbségértékek átlaga -0,16 méter, a medián -1,88 méterre változott, ami a hamis pozitív értékek korrigálásának tudható be. Mivel az erdővel fedett térszínek, valamint a beépített területek javítása esetében kimaszkoltuk azokat a területeket, ahol a rendelkezésünkre álló módszerekkel nem tudtuk megbízhatóan megállapítani a magasságok eltérését, a javítás tényleges értékeléséhez célravezetőbb csak a módosított térségek hibastatisztikáinak áttekintése. Ebben az esetben az eredeti modelltől való eltérések átlaga -1,91 méter, a medián -2,27 méter, a hibák abszolút értékének átlaga pedig 2,81 méter. A korrigált modell esetében az átlagérték -2,56 méter, a medián $-2,59$ méter, az abszolút értékek átlaga pedig 2,88 méter. A hibaátlag alacsonyabb értéket ért el a javítás után, tehát 
a pozitív hibával terhelt cellák aránya csökkent. Ezen kívül a két különbségtérképből előállított hisztogramról is leolvasható, hogy a korrigált modell esetében a medián körül közel kétszer annyi cella csoportosul. Az 1-5,99 és a 6-15,99 méter közötti hibával terhelt cellák a korrigált modellen már a legtöbb esetben a -1- -5,99 méter közötti kategóriába esnek, tehát kijelenthetjük, hogy lényegesen közelebb kerültek a modell által terepi magasságként reprezentált értékekhez. Ezen kívül a jelentős negatív hibával terhelt cellák 25\%-ának értékei szintén közelebb kerültek a valós magasságokhoz, ami szintén megfelel a javítások során elvárt eredményeknek.

\subsubsection{Alkalmazhatóság}

Korábbi kutatásaink során geomorfometriai megközelítésben vizsgáltuk a szabadon hozzáférhető EU-DEM, SRTM-3, ASTER GDEM és SRTM-1 modellek sajátosságait (Józsa, 2015). Síksági, dombsági és alacsony középhegységi térszínek esetében a modelleket szintvonalakból elöállított referenciamodellekkel vetettük össze. A kutatás során arra jutottunk, hogy az SRTM-1 effektív felbontása áll a legközelebb a modell horizontális felbontásához. A hibastatisztikák (négyzetes középhiba, minimum, maximum és átlagos hiba) a korrigálás nélküli modellek esetében hasonló értékeket mutattak, azonban az SRTM-1 egyértelmüen pontosabb eredménytérképek előállítását tette lehetővé a lejtőszög értékek, a modellből levezethető vízrajz és a Topographic Wetness Index (TWI) tekintetében.

A korrigált felszínmodellt a szerzők alkalmazták már az egész országra kiterjedő geomorfológiai kutatásokban a felszínformák automatikus térképezésére, illetve a geomorfológia tájtípusok kategorizálására (Józsa \& Fábián, 2016a). A Korr.DFM-ből levezetett geomorfometriai térképet föleg kiterjedt erdőségeink területén terheli hiba, ahol a síkság helyett tévesen tetőfelszínek, lejtők, völgyek is meghatározásra kerültek. A választott térképezési eljárás (r.geomorphon GRASS GIS eszköz) lehetővé tenné ártéri formák térképezését is, azonban a hibásan meghatározott egységek közül nem lehet automatikusan kiszürni a valós felszínformákat.

A Geresdi-dombság magasabb reliefü területén a korrigált SRTM-1 modell alapján elöállított geomorfometriai térképet Balogh és Schweitzer (2008) által Bátaapáti környezetéről készített geomorfológia térképpel „fuzzy” eljárással vetettük össze. A térbeli pontosság és a főbb morfológiai kategóriák egyezésének vizsgálata során $70 \%$ feletti átfedést mutattunk ki (Józsa \& Fábián, 2016b).

Mindezen eredményekből levonható a következtetés, hogy az SRTM-1 modell információtartalmát és részletességét tekintve kellő körültekintéssel jól alkalmazható geomorfológiai kutatásokban.

\subsection{Szintvonalas állományok}

A korrigált felszínmodellből vektoros formátumban szintvonalas állományokat is generáltunk, ezeket további gyakorlati eredményeknek tekintjük. Az alapszintközt 10 méterben határoztuk meg, figyelembe véve Magyarország domborzati viszonyait, valamint az SRTM-1 modell vertikális felbontását is. A hagyományos térképi ábrázolásoktól eltérően nem tettünk különbséget a síksági, dombvidéki és hegyvidéki térségek esetében alkalmazott magasságközökben. Utólag a szintvonalakat nem simítottuk vagy generalizáltuk, azonban kiszürtük azokat a rövid, valószínüleg visszamaradt hibákat reprezentáló vonalakat, amelyek egy csúcs körül 5 cella sugarú kör alakú mátrix körülhatárolására nem elegendően hosszúak. Az állományt EOV vetületben ESRI shapefile formátumban exportáltuk, megtekintésre Google Earth programba is behívható.

A szintvonalak további felhasználási lehetőségei közé tartozik az OSM adatain alapuló térképi megjelenítésekben a terepviszonyok ábrázolása. A phyghtmap eszköz (Dempwolff, 2009-2017) alkalmazásával a felszínmodellből az OSM által alkalmazott xml formátumban is előállítottunk egy szintvonalas állományt. Fontos azonban megjegyezni, hogy ezek a szintvonalak nem tölthetőek fel az OSM szerverre, céljuk az adatokból előállított térképek pontosítása, szebb vizualizációja.

\section{4. Összegzés}

Munkánk kísérlet volt arra, hogy egy szabadon hozzáférhető, közel globális lefedettséget biztosító magasságmodellt geomorfometriai elemzésekben, DDM-alapú geomorfológiai térképezésben való felhasználásra alkalmassá tegyünk. Az SRTM-1 korrigálása során a modell pozitív irányú változását hibastatisztikákkal, valamint vizuális eljárásokkal is alátámasztottuk. A magassági hibák mértéke, de leginkább a hibával terhelt cellák száma lényegesen kevesebb lett, amely a modell vizuális megjelenésének javulásán túl azt is eredményezte, hogy a felszínformák térképezése során is megbízhatóbb alapmodellnek tekinthető. Akárcsak a hasonló jellegü domborzatmodell-javítási projektek során, jelen esetben is szembetünő, hogy minden hibatípusnál maradtak vissza hibával terhelt cellák. Ezt okozhatja az alkalmazott kiegészító adatok pontatlansága, illetve módszertani hiányosságok, ahol a felszíni objektumokat nehéz volt megkülönböztetni a domborzattól. Mivel a megmaradó hibákat nehéz automatikusan kiszürni a korrigált felszínmodellből levezetett morfometriai paraméterekből is, így a felhasználóknak körültekintően kell eljárni az eredmények értelmezése során.

Módszertani szempontból úgy véljük, hogy a választott szoftverek teljes mértékben megfeleltek a kutatás eredményes megvalósításához. Ekkora raszter fájl esetében sem okozott gondot a lépések kivitelezése GRASS GIS- 
ben. A tavakhoz tartozó cellák javítása volt az egyik legegyszerübben kivitelezhető, viszont sok hibás értéket kiküszöbölő lépése az algoritmusnak. A zajszürés jelentős mértékben javította a modell vizuális megjelenését, valamint a domborzat reálisabb reprezentálását is elősegítette. Annak ellenére, hogy minden cella magassági értékét érintette ez a folyamat, a simítási paraméterek helyes beállítása révén mégsem okozott kimutatható információvesztést. Az algoritmus gyenge pontját egyértelmüen az ártéri erdők korrigálása jelenti, ahol a meanderekkel átszőtt, erdőgazdálkodás alatt álló, nagy kiterjedésű egybefüggő erdőfelületek magasságának megállapításához nem nyújtott elegendő támpontot az erdőszegélyek vizsgálata.

Összességében úgy véljük, hogy az elvégzett munka révén a korrigált SRTM-1 modell hazánkban egységes alapot adhat többféle geomorfológiai kutatás számára is, amivel összehasonlíthatóvá válnának a különböző térszíneken végzett kutatások eredményei. Mindemellett hangsúlyozzuk, hogy figyelembe kell venni a korrigált felszínmodell korlátait, és hogy az alapot nyújtó magassági adat jellege miatt nem hozható létre a földfelszínt pontosan reprezentáló, hibamentes állomány.

\section{Jövóbeni fejlesztések, visszajelzések}

A projekt Józsa Edina doktori kutatásának keretében valósult meg. A korrigált SRTM-1 állományt nem tekintjük véglegesnek, módszertani fejlesztésekkel és az adatgyüjtés időpontjára vonatkozó kiegészítő térképekkel a magassági értékek tovább pontosíthatóak. Éppen ezért, illetve mivel a modell minőségének ellenőrzését elsősorban az általunk ismert és kutatott dél-dunántúli területek esetében végeztük el részletesen, várjuk a javított felszínmodell alkalmazhatóságával, hiányosságaival kapcsolatos visszajelzéseket.

\section{Köszönetnyilvánítás}

A szerzők hálásak a Földrajzi Intézet munkatársainak a kutatás során nyújtott szakmai segítségükért, valamint köszönetet mondanak a PTE Földtudományok Doktori Iskola támogatásáért. Emellett köszönettel tartoznak a Természetföldrajzi Közlemények szerkesztőbizottságának a tanulmány és a felszínmodell nyilvánossá tételében nyújtott közremúködésükért. Továbbá külön köszönet illeti Simon Balázst, aki pusztán tudományos érdeklődésből nagy segítséget nyújtott a módszertani megoldások kidolgozásában.

A jelen tudományos közleményt a szerzők a Pécsi Tudományegyetem alapításának 650. évfordulója emlékének szentelik.

A kutatást az Emberi Erőforrás Támogatáskezelő és az Emberi Erőforrások Minisztériuma támogatta az NTP-NFTÖ-16 projekt keretében (Józsa E.).

\section{Irodalomjegyzék}

Balogh, J., \& Schweitzer, F. (2008). Bátaapáti környezetének geomorfológiai térképe. In Schweitzer, F., Bérci, K., \& Balogh, J. (szerk.), A Bátaapátiban épülő nemzeti radioaktivhulladék-tároló környezetföldrajzi vizsgálata (p. 14). Budapest: MTA Földrajztudományi Kutatóintézet

Dempwolff, A. (2009-2017). Phyghtmap leírás. Letöltve: http://katze.tfiu.de/projects/phyghtmap/ phyghtmap.1.html

Farr, T. G., Rosen, P. A., Caro, E., Crippen, R., Duren, R., Hensley, S., ... Alsdorf, D. (2007). The Shuttle Radar Topography Mission. Reviews of Geophysics, 45, 1-33. doi: $10.1029 / 2005 R G 000183$

Gallant, J. C. (2011). Adaptive smoothing for noisy DEMs. In Hengl, T., Evans, I.S., Wilson, J.P. (Eds.), Geomorphometry 2011 (pp. 37-40). Redlands, CA

Gallant, J. C., Dowling, T. I., Read, A. M., Wilson, N., Tickle, P., \& Inskeep, C. (2011). 1 second SRTM Derived Digital Elevation Models User Guide. Geoscience Australia, Letöltve: www.ga.gov.au/ topographic-mapping/digital-elevation-data.html

Gallant, J. C., Read, A. M., \& Dowling, T. I. (2012). Removal of tree offsets from SRTM and other digital surface models. International Archives of the Photogrammetry, Remote Sensing and Spatial Information Sciences, Volume XXXIX-B4, 275-280.

Hansen, M. C., Potapov, P. V., Moore, R., Hancher, M., Turubanova, S. A., Tyukavina, A., ... Townshend, J. R. G. (2013). High-Resolution Global Maps of 21st-Century Forest Cover Change. Science, 342, 800-853. doi: 10.1126/science. 1244693 Letöltve: http://earthenginepartners.appspot.com/ science-2013-global-forest

Józsa, E., Fábián, Sz. Á., \& Kovács M. (2014). An evaluation of EU-DEM in comparison with ASTER GDEM, SRTM and contour-based dems over the eastern mecsek mountains. Hungarian Geographical Bulletin, 63(4), 401-423. doi: 10.15201/hungeobull.63.4.3

Józsa, E. (2015). An evaluation of EU-DEM and SRTM1 in comparison with ASTER GDEM, SRTM3 and reference DEMs - geomorphometric approaches. In Boda, J. (szerk.), Az elmélet és a gyakorlat találkozása a térinformatikában: Térinformatikai Konferencia és Szakkiállitás VI. (pp. 117-125). Debrecen: Debrecen Egyetemi Kiadó

Józsa, E., \& Fábián, Sz. Á. (2016a). Mapping landforms and geomorphological landscapes of Hungary using GIS techniques. Studia Geomorphologica Carpatho Balcanica, 50(1), 19-31. 
Józsa E., \& Fábián, Sz. Á. (2016b). Domborzatmodell alapú geomorfometriai térképezés pontosításának lehetősége a jellemző gerinc-völgy távolság alkalmazásával. In Pajtókné Tari, I. \& Tóth, A. (szerk.), Magyar Földrajzi Napok 2016: Absztraktkötet. VIII. Magyar Földrajzi Konferencia, XVI. Geográfus Doktoranduszok Országos Konferenciája, Oktatás-módszertani és Földrajztanári Konferencia (pp. 48-49). Eger: Magyar Földrajzi Társaság

Köthe, R., \& Bock, M. (2009). Preprocessing of Digital Elevation Models - derived from Laser Scanning and Radar Interferometry - for Terrain Analysis in Geosciences. In Purves, R., Gruber, S., Hengl, T., Straumann, R. (Eds.), Proceedings of Geomorphometry 2009 (pp. 155-161). Zürich, Svájc

Mélykúti, G. (2007). Topográfiai adatbázisok. BMEEOFTASJ3 segédlet a BME Építómérnöki Kar hallgatói részére. Elektronikus jegyzet, Budapest: Budapesti Müszaki Egyetem

NASA JPL hírek (2014. szeptember 23.). U.S. Releases Enhanced Shuttle Land Elevation Data. Letöltve: https:// www.jpl.nasa.gov/news/news.php?release $=2014-321$

Neteler, M. (2005). SRTM and VMAP0 data in OGR and GRASS. GRASS Newsletter, 3, 2-6.

OpenStreetMap contributors 2015 Planet dump. Adatfájl elérése 2016. január 8-án az 160104.osm adatbázisból, Letöltve: http://planet.openstreetmap.org

Reuter, H. I., Strobl, P., \& Mehl, W. (2011). How to merge a DEM? In Hengl, T., Evans, I.S., Wilson, J.P. (Eds.), Geomorphometry 2011 (pp. 87-90). Redlands, CA

Rodriguez, E., Morris, C.S., Belz, J., Chapin, E., Martin, J., Daffer, W., \& Hensley, S. (2005). An Assessment of the SRTM Topographic Products. Technical Report JPL D-31639, Jet Propulsion Laboratory, Pasadena, USA
Seres, A., \& Dobos, E. (2009). Területhasználati térkép készítése müholdfelvételek alapján az SRTM magasságmodell pontosítására. Geoinformatika és domborzatmodellezés 2009, A HunDEM 2009 és GeoInfo 2009 konferencia és kerekasztal válogatott tanulmányai (pp. 1-14). Miskolc

Slater, J.A., Garvey, G., Johnston, C., Haase, J., Heady, B., Kroenung, G., \& Little, J. (2006). The SRTM data „finishing” process and products. Photogrammetric Engineering and Remote Sensing, 72(3), 237-247.

SRTM Water Body Database V2.1 (2003). Letöltve: https://dds.cr.usgs.gov/srtm/version2_1/SWBD/

Stevenson, J. A., Sun, X., \& Mitchell, N. C. (2010). Despeckling SRTM and other topographic data with a denoising algorithm. Geomorphology, 114(3), 238-252. doi: 10.1109/TVCG.2007.1065

Sun, X., Rosin, P. L., Martin, R. R., \& Langbein, F.C. (2007). Fast and Effective Feature-Preserving Mesh Denoising. IEEE Transactions on Visualisation and Computer Graphics, 13, 925-938. doi: 10.1016/j.geomorph.2009.07.006

Telbisz, T., Székely, B., \& Timár, G. (2013). Digitális Terepmodellek - Adat, látvány, elemzés. Budapest: Eötvös Loránd Tudományegyetem Természettudományi Kar, Földrajz- és Földtudományi Intézet, Természetföldrajzi Tanszék

Ungvári, Zs. (2015). Valós tengerszint feletti magasságok meghatározása erdőfelületek alatt SRTM és CORINE adatok alapján. In Boda, J. (szerk.), Az elmélet és a gyakorlat találkozása a térinformatikában: Térinformatikai Konferencia és Szakkiállitás VI. (pp. 429-436). Debrecen: Debrecen Egyetemi Kiadó

USGS Shuttle Radar Topography Mission (SRTM) 1 Arc-Second Global termékleirás. Letöltve: https://ta.cr.usgs.gov/SRTM1Arc 